\title{
Penerapan Model Picture And Picture Dalam Meningkatkan Aktivitas Dan Hasil Belajar Pembelajaran Tematik Siswa Kelas II Sekolah Dasar
}

\author{
Herman \\ Universitas Bengkulu \\ hermandatuk1005@gmail.com \\ Irfan Supriatna \\ Universitas Bengkulu \\ irfansupriatna@unib.ac.id
}

\begin{abstract}
This study aims to improve the activities and learning outcomes of thematic learning in grade II elementary school students through the application of picture and picture models. The research method used was classroom action research (clascroom action research) with a cycle of Kemmis and Taggart using 4 stages namely planning, action, observation, reflection. Research subjects with 27 students consisting of 14 men and 13 women. The results of the study stated that an increase in student activity and learning outcomes in thematic learning in class II, this can be seen from the increase in the average acquisition of student activity scores in the first cycle obtained an average score of 31 increased to 35.5 with a good category in the second cycle. Then the learning outcomes are proven from the average value and the percentage of student learning in the form of cognitive, affective and psychomotor values. Cognitive Value The highest average value is in the natural science subjects at 84.16 with the percentage of student learning reaching $100 \%$ and the lowest average value in mathematics subjects at 80.83 with the percentage of student learning only reaching $83.39 \%$. Affective value, the highest percentage of criteria namely in SBK, Natural Sciences and Civics reached $88.88 \%$ or as many as 24 people and the lowest percentage of criteria namely in mathematics subjects only reached $81.48 \%$ or as many as 22 people. Psychomotor scores, the highest percentage of criteria namely SBK, Natural Sciences and Civics reached $88.88 \%$ or as many as 24 people and the lowest percentage of criteria namely in Mathematics and Social Sciences subjects only reached $85.18 \%$ or as many as 23 people. The conclusion is that the application of picture and picture models in grade II elementary schools can increase the activities and learning outcomes of thematic learning.
\end{abstract}

Keywords: picture and picture models, student activities, student learning outcomes, thematic learning

\section{Pendahuluan}

Dunia pendidikan dewasa ini telah mengalami perkembangan secara pesat, hal ini terlihat jelas dengan adanya dukungan tekhnologi yang terus maju, dunia pendidikan dimungkinkan dapat mempersiapkan sumber daya manusia yang mampu bersaing di dalam era globalisasi. Pendidikan merupakan suatu proses pembentukan kecakapan mendasar secara intelektual dan emosional sesama manusia. Pendidikan merupakan salah satu aspek yang bersifat sangat penting dalam kehidupan manusia, oleh karena itu pendidikan sangat dibutuhkan dalam kalangan masyarakat di seluruh belahan dunia. 
Untuk mencapai keberhasilan tujuan pendidikan tersebut, maka pemerintah selalu mengupayakan penyelenggaraan perbaikan-perbaikan untuk meningkatkan mutu pendidikan dari berbagai jenis dan jenjang.Adapun upaya yang telah dilakukan oleh pemerintah yaitu dengan meningkatkan kualitas pendidikan dan tenaga kependidikan, penyempurnaan kurikulum, dan penyediaan sarana serta prasarana.

Pendidikan di sekolah dasar pada hakikatnya harus memperhatikan karakteristik siswa pada usia sekolah dasar (SD). Menurut Piaget (dalam djamarah, 2008) pada usia SD (7-12 tahun) perkembangan mental anak pada masa operasional konkret, pada dasarnya siswa belajar melalui objek yang konkret. Untuk menanggapi perkembangan pada usia sekolah dasar (SD) maka diperlukan interaksi belajar mengajar. Oleh sebab itu, dalam proses pembelajaran harus memperhatikan karakteristik siswa pada usia sekolah dasar (SD). Guru harus dapat menerapkan metode pembelajaran yang sesuai dengan kebutuhan dan karakteristik siswa.Adapun karakteristik dan kebutuhan peserta didik pada usia SD sebagai berikut : (1) anak SD senang bermain (2) senang bergerak (3) senang bekerja dalam kelompok,(4) senang merasakan melakukan/memperagakan sesuatu secara langsung.

Pendidikan yang mampu mendukung pembangunan masa depan adalah pendidikan yang mampu mengoptimalkan seluruh bakat dan kemampuan yang dimiliki anak. Sejalan dengan pendapat di atas, Pidarta juga menyatakan bahwa melalui pendidikan seseorang dapat mengoptimalkan bakat, pribadi dan potensi-potensi lainnya ke arah yang positif.

Ketika proses pembelajaran berlangsung, peserta didik tidak merasa sedang mempelajari satu mata pelajaran saja, tetapi peserta didik akan mempelajari lebih dari satu mata pelajaran.

Menurut Kunandar, model pembelajaran tematik memiliki beberapa kelebihan, yaitu:

1. Menyenangkan karena berangkat dari minat dan kebutuhan peserta didik.

2. Memberikan pengalaman dan kegiatan belajar mengajar yang relevan dengan tingkat perkembangan dan kebutuhan peserta didik.

3. Hasil belajar dapat bertahan lama karena lebih berkesan dan bermakna.

4. Mengembangkan keterampilan berpikir peserta didik sesuai dengan persoalan yang dihadapi.

5. Menumbuhkan keterampilan sosial melalui kerjasama.

6. Memiliki sikap toleransi, komunikasi, dan tanggap terhadap gagasan orang lain.

7. Menyajikan kegiatan yang bersifat nyata sesuai dengan persoalan yang dihadapi dalam lingkungan peserta didik.

Berdasarkan pengalaman dan wawancara yang peneliti lakukan pada saat pelaksanaan pembelajaran di kelas II di SDN 60 Kota Bengkulu, terdapat kendalakendala dalam pelaksanaan pembelajaran antara lain: (1) guru kurang maksimal dalam menggunakan model atau metode pembelajaran; (2) guru kurang maksimal menggunakan media pembelajaran; (3) banyaknya materi yang ada pada kurikulum sekolah, sehingga pembelajaran bertema sedikit sulit untuk diterapkan; (4) Guru kelas yang belum terlalu paham tentang pembelajaran tematik;(5) penggunaan buku yang masih terpisah sesuai mata pelajaran; (6) hasil belajar yang masih rendah. Berdasarkan permasalahan ini dapat disimpulkan satu permasalahan inti yaitu pembelajaran tematik tersebut belum pernah dilaksanakan di SDN 60 Kota Bengkulu secara optimal dan dalam kegiatan belajar mengajar metode yang digunakan belum melibatkan siswa secara aktif dalam proses pembelajaran sehingga siswa menjadi pasif. Hal inilah yang menyebabkan rendahnya hasil belajar siswa, yaitu nilai ratarata siswa di kelas II SDN 60 Kota Bengkulu, adalah 68,92. Nilai tersebut dikatakan belum tuntas, karena proses pembelajaran di kelas dikatakan tuntas secara klasikal 
apabila $75 \%$ siswa dikelas mendapat nilai $\geq 70$ dan nilai tes dikatakan tuntas apabila secara perorangan memperoleh nilai 70. (Depdiknas, 2006).

Berdasarkan permasalahan tersebut penelitiingin memperbaiki pembelajaran sehingga dapat meningkatkan hasil belajar dan aktivitas belajar siswa. Seperti yang dikemukakan Winarni (2012), hasil belajar adalah sebagai pencapaian seorang siswa yang telah melakukan pembelajaran sehingga membuat siswa yang sebelumnya tidak mengerti menjadi mengerti.

Untuk meningkatkan hasil belajar dan aktivitas pembelajaran siswa, banyak hal yang telah dilakukan pihak sekolah, antara lain telah melakukan penyempurnaan kurikulum, pengadaan buku paket, pelatihan guru dan bantuan penyediaan alat peraga pembelajaran. Namun faktor terpenting yang menentukan kualitas pembelajaran adalah seorang guru, dalam hal ini guru harus pandai dalam memilih metode yang dapat membuat siswa aktif dalam proses pembelajaran.

Seorang guru dalam menyajikan pelajaran harus merencanakan metode yang akan digunakan, karena metode sangat menentukan tercapainya tujuan pembelajaran. Guru harus berusaha menggunakan metode yang tepat sehingga siswa tidak merasa bosan dan dapat meraih hasil yang optimal.

Guru dituntut untuk mengembangkan kegiatan pembelajaran yang mampu meningkatkan kompetensi, baik dalam ranah kognitif, afektif maupun psikomotorik. Strategi pembelajaran yang berpusat pada siswa dan penciptaan suasana yang menyenangkan dalamproses pembelajaran, pengetahuan dan keterampilan yang berguna bagi siswa dalam kehidupannya sehari-hari serta sikap dalam rangka mewujudkan manusia yang berkualitas, bertanggung jawab bagi diri sendiri, masyarakat, bangsa dan negara serta bertanggung jawab kepada Tuhan Yang Maha Esa.

Guru harus lebih banyak memberikan peran kepada siswa sebagai subjek belajar, Guru merancang proses belajar mengajar yang melibatkan siswa secara integratif dan komprehensif pada aspek kognitif, afektif dan psikomotorik sehingga tercapai indikator yang diharapkan. Untuk meningkatkan aktivitas pembelajaran dan menanamkan nilai-nilai untuk membentuk karakter siswa diperlukan situasi, cara dan strategi yang tepat serta melibatkan siswa secara aktif baik pikiran, pendengaran, penglihatan, dan psikomotor dalam proses pembelajaran.

Pembelajaran yang tepat untuk melibatkan siswa secara keseluruhan adalah pembelajaran tematik dengan menerapkan model picture and picture. Pembelajaran tematik merupakan suatu strategi pembelajaran yang melibatkan beberapa mata pelajaran untuk memberikan pengalaman yang bermakna bagi siswa. Model picture and picture merupakan model pembelajaran yang mengandalkan gambar sebagai media dalam proses pembelajaran, memiliki ciri aktif, inovatif, kreatif dan menyenangkan. Dalam proses pembelajaran tematik dengan menerapkan model picture and picture ini sangat menuntut keaktifan siswa, sehingga akan meningkatkan hasil belajar dan aktivitas belajar siswa yang lebih optimal.

Dengan adanya aktivitas siswa dalam proses pembelajaran terciptalah belajar aktif. Seperti yang dikemukakan Natawijaya bahwa belajar aktif adalah suatu sistem belajar mengajar yang menekankan keaktifan siswa secara fisik, mental intelektual dan emosional guna memperoleh hasil belajar berupa perpaduan antara aspek kognitif, afektif dan psikomotor..

Berdasarkan uraian di atas maka dapat dikatakan bahwa pembelajaran tematik dengan menerapkan model picture and picture ini dirasa sangat tepat untuk dilakukan sebagai upaya peningkatan hasil belajar dan aktivitas belajar siswa kelas II SDN 60 Kota Bengkulu. Karena dengan melaksanakan pembelajaran tematik dengan menerapkan model picture and picture ini siswa dapat belajar dengan aktif dan menyenangkan. 


\section{Metode}

Metode penelitian ini adalah Penelitian Tindakan Kelas (Classroom Action Research) dalam Sugiono, 2008 yaitu penelitian yang dilakukan oleh guru didalam kelas atau disekolah tempat iamengajar dengan penekanan pada penyempurnaan atau peningkatan proses dan praktis pembelajaran. Penelitian Tindakan Kelas ini memilki empat tahapan yaitu : (1) perencanaan, (2) pelaksanaan, (3) observasi, (4) refleksi.

Adapun subjek penelitian adalahguru dan siswa kelas II di SDN 60 Kota Bengkulu pada pembelajaran tematik dengan siswa yang berjumlah 27 orang siswa, yaitu 14 orang siswa laki-laki dan 13 orang siswa perempuan.

Penelitian tindakan kelas ini dilaksanakan di kelas II SDN 60 Kota Bengkulu dengan penelitian tindakan kelas model siklus. Model ini dikembangkan oleh Kemmis dan Mc Taggart (dalam Wiriaatmadja, 2009). Model penelitian tindakan kelas ini mengandung empat tahapaan, yaitu: (1) perencanaan (planning), perencanaan yang disusun berdasarkan atas permasalahan yang yang dihadapi oleh guru dan siswa dalam pembelajaran (2) Tindakan (action), merupakan realisasi dari perencanaan yang telah di susun (3) Observasi (observation), merupakan tahap pengamatan terhadap tindakan yang telah dilaksanakan, (4) refleksi (reflection) merupakan tahap yang dilakukan peneliti untuk mengidentifikasi kelemahan-kelemahan yang masih terjadi pada saat proses pembelajaran yang bertujuan untuk merumuskan langkahlangkah pembelajaran yang harus dilakukan peneliti pada siklus yang selanjutnya. Secara singkatnya, tahap-tahap dalam penelitian tindakan kelas, yaitu:

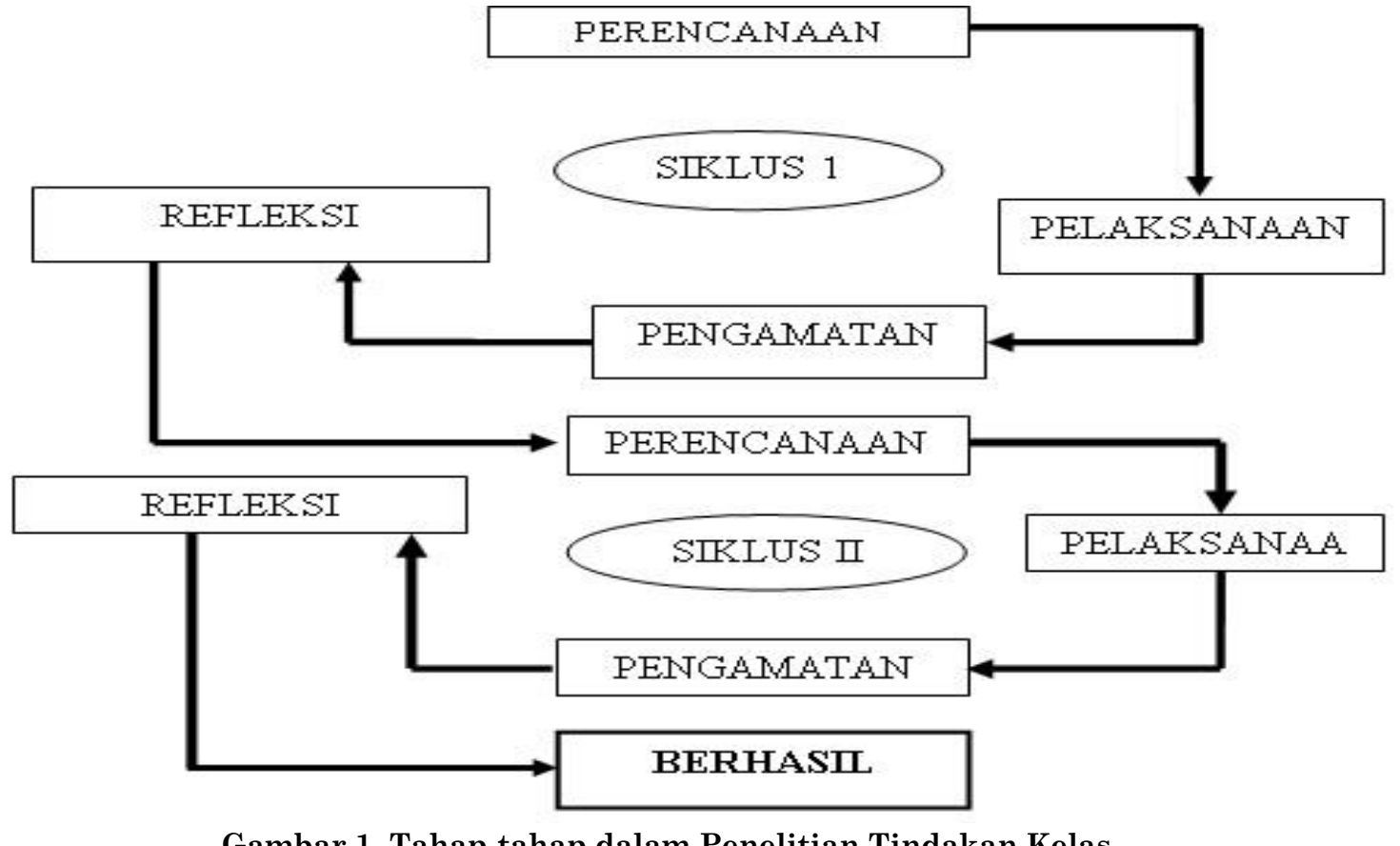

Gambar 1. Tahap-tahap dalam Penelitian Tindakan Kelas

Sumber: Buku Penelitian Tindakan Kelas Arikunto (2009:16)

Hasil

Aktivitas Siswa

Berdasarkan data pengamat pada siklus I skor rata-rata aktivitas siswa sebesar 31 berada pada kategori baik. Keunggulan pada aktivitas siswa siklus I antara lain siswa aktif secara bergiliran untuk mengurutkan atau memasangkan gambar-gambar yang ada dalam kegiatan pembelajaran, siswa aktif dan bersemangat dalam memasangkan 
gambar agar menjadi gambar yang utuh. Pada kegiatan ini aktivitas belajar siswa lebih baik karena siswa dituntut aktif berpartisipasi dalam kegiatan pembelajaran.

Keunggulan-keunggulan pada siklus I ini akan tetap dipertahankan pada siklus II. Sementara aspek yang menjadi kelemahan pada siklus I ini merupakan acuan untuk perbaikan pada siklus II agar pembelajaran tematik dengan mengguanakan model picture and picture ini dapat mencapai suatu keberhasilan. Berdasarkan pengamatan aktivitas siswa siklus II terdapat peningkatan skor aktivitas siswa yaitu 35,5 berada pada kategori baik. Hal ini tidak lepas dari usaha guru untuk memperbaiki kelemahan aktivitas siswa pada siklus I sehingga aktivitas siswa pada sklus II menjadi lebih baik lagi.

Keberhasilan ini diantaranya nampak dari keberhasilan guru dalam mengupayakan agar siswa merespon motivasi yang diberikan oleh guru sehingga terbangkitkan rasa ingin tahunya, dapat menanggapi pertanyaan-pertanyaan dari guru dan berani mengemukakan pendapatnya. Respon adalah setiap perilaku pada hakekatnya merupakan tanggapan atau balasan (respon) terhadap rangsangan atau stimulus. Dapat dikatakan bahwa respon atau tanggapan adalah reaksi yang berupa tanggapan atau jawaban terhadap stimulus yang diterimanya yang berupa informasi, berita dan pengetahuan.

Pada siklus II ini siswa mendapat bimbingan saat menyelesaikan persoalan dalam proses pembelajaran. Siswa dibimbing untuk memahami persoalan dalam proses pembelajaran, siswa mendapat kesempatan untuk menyelesaikan permasalahan bersama dengan anggota kelompoknya, dan siswa bisa menyelesaikan kesulitan yang dihadapi.

Pada siklus II ini juga siswa sudah baik dan tertib melaporkan hasil diskusi, siswa lain menanggapi, dan siswa aktif bertanya tentang hal-hal yang belum dipahami dalam diskusi. Dengan bimbingan guru yang sudah optimal selama kegiatan pembelajaran berlangsung sehingga aktivitas siswa lebih meningkat dari siklus I. Siswa tidak ragu lagi dalam menyimpulkan materi pelajarandengan bimbingan guru, siswa mendapat kesempatan untuk menyimpulkan materi pelajaran dengan katakata sendiri dan siswa merasa sangat bangga dengan diberikannya penghargaan bagi siswa yang berani menyimpulkan materi pelajaran.

\section{Pembahasan}

\section{Hasil Belajar Siswa}

Hasil belajar siswa dinilai dari tiga ranah penilaian belajar yaitu ranah kognitif, afektif, dan psikomotor. Sesuai dengan teori Bloom (dalam sudjana, 2006) menyatakan bahwa hasil belajar dalam rangka studi, dicapai melalui tiga kategori yakni ranah kognitif, afektif, dan psikomotor.

\section{a. Nilai Kognitif}

Penilaian kognitif pembelajaran tematik dengan model picture and picture menggunakan sebuah tes. Nilai Tes dideskripsikan hasil belajar siswa melalui tes pada siklus I.

Siklus I dilaksanakan sesuai skenario / rencana pembelajaran tematik yang telah disusun dengan menggunakan tema untuk mengkaitkan beberapa mata pelajaran.Pada akhir pembelajaran diadakan tes evaluasi yang disusun oleh guru. Tes ini digunakan untuk mengetahui hasil prestasi belajar siswa pada tema"lingkungan". Nilai rata-rata yang diperoleh pada siklus I adalah 7,88 untuk mata pelajaran SBK, 8,48 untuk mata pelajaran IPA, 8,14 untuk mata pelajaran PKn, 7,77 untuk mata pelajaran IPS 7,95 untuk mata pelajaran Bahasa Indonesia, dan 6,86 untuk mata pelajaran Matematika. 
Prosentase ketuntasan belajar yang dicapai pada siklus I adalah 92,59 untuk SBK, 88,89 untuk mata pelajaran IPA, 85,19 untuk mata pelajaran PKn, 74,08 untuk mata pelajaran IPS ,85,19 untuk mata pelajaran Bahasa Indonesia dan 51,86 untuk mata pelajaran Matematika. Prosentase ketuntasan belajar terendah yaitu pada mata pelajaran Matematika karena prosentase ketuntasannya hanya mencapai 51,86\%, sedangkan prosentase ketuntasan belajar tertinggi yaitu pada mata pelajaran SBK yaitu mencapai $92,59 \%$.

Oleh karena itu telah dilakukan perbaikan dengan melaksanakan siklus II.Nilai ratarata yang diperoleh pada siklus II melalui pertemuan 1 dan 2 adalah 7,96 untuk mata pelajaran SBK, 8,66 untuk mata pelajaran IPA, 8,22 untuk mata pelajaran PKn, 8,12 untuk mata pelajaran IPS , 7,98 untuk mata pelajaran Bahasa Indonesiadan 7,92 untuk mata pelajaran Matematika. Prosentase ketuntasan belajar yang dicapai pada siklus II adalah 92,59\% untuk SBK, 100\% untuk mata pelajaran IPA, 92,59 \% untuk mata pelajaran PKn, 96,30\% untuk mata pelajaran IPS , 88,89\% untuk mata pelajaran Bahasa Indonesia, dan 81,49 \% untuk mata pelajaran Matematika. Prosentase ketuntasan belajar terendah yaitu pada mata pelajaran Matematika karena prosentase ketuntasannya hanya mencapai $81,49 \%$, sedangkan prosentase ketuntasan belajar tertinggi yaitu pada mata pelajaran IPA yaitu mencapai $100 \%$.

Berdasarkan uraiandi atas dapat dilihat bahwa ketuntasan belajar siswa pada siklus II ini sudah bisa dikatakan tuntas karena karena berdasarkan acuan KTSP yang menyebutkan bahwa prosentase ketuntasan belajar siswa $75 \%$ siswa mendapat nilai 7,5 untuk mata pelajaran SBK, IPA, PKn dan IPS, 75\% siswa mendapat nilai 7,0 untuk mata pelajaran Matematika dan 75\% siswa mendapat nilai 7,5 untuk mata pelajaran Bahasa Indonesia. Hasil belajar siswa pada siklus II ini sudah sangat memuaskan, dengan demikian pendekatan lingkungan pada pembelajaran tematik di kelas IIB SD IT Generasi Rabbani Kota Bengkulu menunjukkan hasil yang memuaskan.

\section{b. Nilai Afektif}

Berdasarkan data pada tabel penilaian afektif siklus I, dapat dikatakan bahwa dari 27 orang siswa pada pengamatan afektif siswa selama proses pembelajaran tematik dengan model picture and picture sebagian besar masih terdapat dalam kategori cukup.

Hasil analisis nilai afektif siswa pada siklus I, untuk mata pelajaran SBK kriteria baik sebesar $81,48 \%$ atau sebanyak 22 orang, sedangkan yang memperoleh kriteria cukup sebesar $18,51 \%$ atau sebanyak 5 orang dan untuk nilai afektif kelas sebesar 7,1 dengan kategori Baik. Mata pelajaran IPA kriteria baik sebesar 77,77 \% atau sebanyak 21 orang, sedangkan yang memperoleh kriteria cukup sebesar $22,22 \%$ atau sebanyak 6 orang dan untuk nilai afektif kelas sebesar 6,8 dengan kategori Cukup. Mata pelajaran PKn kriteria baik sebesar $81,48 \%$ atau sebanyak 22 orang, sedangkan yang memperoleh kriteria cukup sebesar $18,51 \%$ atau sebanyak 5 orang dan untuk nilai afektif kelas sebesar 6,72 dengan kategori Cukup. Mata pelajaran IPS kriteria baik sebesar $81,48 \%$ atau sebanyak 22 orang, sedangkan yang memperoleh kriteria cukup sebesar $18,51 \%$ atau sebanyak 5 orang dan untuk nilai afektif kelas sebesar 6,61 dengan kategori Cukup. Mata pelajaran Matematika kriteria baik sebesar 77,77 $\%$ atau sebanyak 21 orang, sedangkan yang memperoleh kriteria cukup sebesar 22,22 $\%$ atau sebanyak 6 orang dan untuk nilai afektif kelas sebesar 6,54 dengan kategori Cukup.

Data tersebut meningkat pada tabel penilaian afektif siswa siklus II, dengan hasil analisis nilai afektif siswa pada siklus II, untuk mata pelajaran SBK kriteria baik sebesar 88,88 \% atau sebanyak 24 orang, sedangkan yang memperoleh kriteria cukup sebesar $11,11 \%$ atau sebanyak 3 orang dan untuk nilai afektif kelas sebesar 7,54 dengan kategori Baik. Mata pelajaran IPA kriteria baik sebesar 88,88 \% atau sebanyak 24 orang, sedangkan yang memperoleh kriteria cukup sebesar $11,11 \%$ atau sebanyak 3 orang dan untuk nilai afektif kelas sebesar 7,72 dengan kategori Baik. 
Mata pelajaran PKn kriteria baik sebesar 88,88\% atau sebanyak 24 orang, sedangkan yang memperoleh kriteria cukup sebesar $11,11 \%$ atau sebanyak 3 orang dan untuk nilai afektif kelas sebesar 7,51 dengan kategori Baik. Mata pelajaran IPS kriteria baik sebesar $85,18 \%$ atau sebanyak 23 orang, sedangkan yang memperoleh kriteria cukup sebesar 14,81\% atau sebanyak 4 orang dan untuk nilai afektif kelas sebesar 7,36 dengan kategori Baik. Mata pelajaran Matematika kriteria baik sebesar 81,48\% atau sebanyak 22 orang, sedangkan yang memperoleh kriteria cukup sebesar $18,51 \%$ atau sebanyak 5 orang dan untuk nilai afektif kelas sebesar 7,32 dengan kategori Baik.

\section{c. Nilai Psikomotor}

Penilaian psikomotor diamati selama proses pembelajaran berlangsung. Ranah psikomotor yang dinilai terdiri dari tiga aspek yaitu, aspek menirukan (menyesuaikan hasil LDS dengan media), aspek memanipulasi (membuat jawaban pada LDS dengan tepat dan berani membacakan hasilnya di depan kelas), dan aspek artikulasi (menempel gambar pada media dengan tepat sesuai dengan jawaban pada LDS di depan kelas)..

Hasil analisis nilai psikomotor siswa pada siklus I, untuk mata pelajaran SBK kriteria baik sebesar 77,77 \% atau sebanyak 21 orang, sedangkan yang memperoleh kriteria cukup sebesar $22,22 \%$ atau sebanyak 6 orang dan untuk nilai psikomotor kelas sebesar 6,77 dengan kategori Cukup. Mata pelajaran IPA kriteria baik sebesar 74,07 $\%$ atau sebanyak 20 orang, sedangkan yang memperoleh kriteria cukup sebesar 25,92 $\%$ atau sebanyak 7 orang dan untuk nilai psikomotor kelas sebesar 6,61 dengan kategori Cukup. Mata pelajaran PKn kriteria baik sebesar 81,48 \% atau sebanyak 22 orang, sedangkan yang memperoleh kriteria cukup sebesar 18,51\% atau sebanyak 5 orang dan untuk nilai psikomotor kelas sebesar 6,5 dengan kategori Cukup. Mata pelajaran IPS kriteria baik sebesar $81,48 \%$ atau sebanyak 22 orang, sedangkan yang memperoleh kriteria cukup sebesar 18,51\% atau sebanyak 5 orang dan untuk nilai psikomotor kelas sebesar 6,61 dengan kategori Cukup. Mata pelajaran Matematika kriteria baik sebesar $77,77 \%$ atau sebanyak 21 orang, sedangkan yang memperoleh kriteria cukup sebesar $22,22 \%$ atau sebanyak 6 orang dan untuk nilai psikomotor kelas sebesar 6,43 dengan kategori Cukup.

Data tersebut meningkat pada tabel penilaian psikomotor siswa siklus II, dengan hasil analisis nilai psikomotor siswa pada siklus II, untuk mata pelajaran SBK kriteria baik sebesar 88,88 \% atau sebanyak 24 orang, sedangkan yang memperoleh kriteria cukup sebesar 11,11\% atau sebanyak 3 orang dan untuk nilai psikomotor kelas sebesar 7,65 dengan kategori Baik. Mata pelajaran IPA kriteria baik sebesar 88,88 \% atau sebanyak 24 orang, sedangkan yang memperoleh kriteria cukup sebesar $11,11 \%$ atau sebanyak 3 orang dan untuk nilai psikomotor kelas sebesar 7,91 dengan kategori Baik. Mata pelajaran PKn kriteria baik sebesar 88,88\% atau sebanyak 24 orang, sedangkan yang memperoleh kriteria cukup sebesar $11,11 \%$ atau sebanyak 3 orang dan untuk nilai psikomotor kelas sebesar 7,28 dengan kategori Baik. Mata pelajaran IPS kriteria baik sebesar $85,18 \%$ atau sebanyak 23 orang, sedangkan yang memperoleh kriteria cukup sebesar $14,81 \%$ atau sebanyak 4 orang dan untuk nilai psikomotor kelas sebesar 7,51 dengan kategori Baik. Mata pelajaran Matematika kriteria baik sebesar $85,18 \%$ atau sebanyak 23 orang, sedangkan yang memperoleh kriteria cukup sebesar $14,81 \%$ atau sebanyak 4 orang dan untuk nilai psikomotor kelas sebesar 7,39 dengan kategori Baik.

\section{Simpulan}

Pembelajaran tematik dengan model picture and picture dapat meningkatkan aktivitas pembelajaran di kelas II SDN 60 Kota Bengkulu. Peningkatan perolehan rata-rata skor terhadap aktivitas guru dan juga siswa yaitu pada aktivitas guru diperoleh skor 31,25 dengan kategori baik pada siklus I, meningkat menjadi 36 dengan kategori baik di siklus II, serta pada aktivitas siswa diperoleh rata-rata skor 31 dengan 
kategori baik pada siklus I , meningkat menjadi 35,5 dengan kategori baik pada siklus II.

Pembelajaran tematik dengan model picture and picture dapat meningkatkan hasil belajar siswa. Hal ini dibuktikan dari nilai rata-rata hasilbelajar dan prosentase belajar siswa berupa nilai kognitif, afektif dan psikomotor.

a. Nilai Kognitif

Nilai rata-rata hasil belajar tertinggi yaitu pada mata pelajaran IPA sebesar 8,66 dengan prosentase belajar siswa mencapai $100 \%$ dan nilai rata-rata hasil belajar terendah yaitu pada mata pelajaran Matematika sebesar 7,92 dengan prosentase belajar siswa hanya mencapai $81,49 \%$.

b. Nilai afektif

Untuk nilai afektif dengan prosentase kriteria baik tertinggi yaitu pada mata pelajaran SBK, IPA dan PKn mencapai 88,88\% atau sebanyak 24 orang. Untuk nilai afektif dengan prosentase kriteria baik terendah yaitu pada mata pelajaran Matematika hanya mencapai $81,48 \%$ atau sebanyak 22 orang.

c. Nilai Psikomotor

Untuk nilai psikomotor dengan prosentase kriteria baik tertinggi yaitu pada mata pelajaran SBK, IPA dan PKn mencapai 88,88\% atau sebanyak 24 orang. Untuk nilai psikomotorik dengan prosentase kriteria baik terendah yaitu pada mata pelajaran Matematika dan IPS hanya mencapai $85,18 \%$ atau sebanyak 23 orang.

\section{Saran}

Setelah mengadakan penelitian tindakan kelas yang dilaksanakan di kelas II SDN 60 Kota Bengkulu tentang penerapan model picture and picture dalam meningkatkan aktivitas dan hasil belajar pembelajaran tematik di kelas II SD peneliti menyarankan,

a. Bagi guru :

1) Diharapkan dapat menerapkan pembelajaran tematik dengan model picture and picture agar dapat memberikan suasana baru dalam proses pembelajaran sebagai upaya untuk tercapainya tujuan pembelajaran yang diharapkan.

2) Disarankan dalam menerapkan pembelajaran tematik dengan model picture and picture dengan memperhatikan langkah-langkah berikut ini:

3) Guru harus melaksanakan model picture and picture dengan menyiapkan dan menggunakan media gambar sebagai sumber belajar sesuai tema pembelajaran.

4) Guru harus menjelaskan langkah-langkah kegiatan yang akan dilakukan secara jelas.

5) Guru harus membimbing siswa dalam melakukan kegiatan pembelajaran menggunakan media gambar.

6) Guru harus membimbing siswa untuk melaporkan hasil pengamatannya.

b. Bagi penelitian selanjutnya disarankan agar dilakukan penelitian lanjutan mengenai penerapan model picture and picture pada pembelajaran tematik dengan memperhatikan subjek penelitian yang lebih luas. Peneliti mengemukakan masih terdapat beberapa kekurangan dalam penelitian ini, diharapkan bagi penelitian selanjutnya, kekurangan-kekurangan ini nantinya dapat dijadikan bahan rujukan untuk melakukan penelitian yang lebih lanjut.

\section{Referensi}

Arikunto. 2009. Penelitian Tindakan Kelas. Jakarta: PT. Bumi Aksara.

Depdiknas. 2006. Kurikulum Tingkat Satuan Pendidikan SD. Jakarta: Depdiknas

Djamarah. 2008. Psikologi Belajar. Jakarta: Rineka Cipta 
Kunandar. 2007. Guru Profesional. Jakarta: Raja Grafindo Persada.

Sudjana, Nana. 2006. Penilaian Hasil Proses Belajar Mengajar. Bandung: Rosdakarya. Sugiyono. 2008. Metode Penelitian Pendidikan. Bandung: Alfabeta.

Undang-Undang Republik Indonesia No. 20 Tahun 2013. Jogjakarta: Laksana

Wardani. 2006. Penelitian Tindakan Kelas. Jakarta: Universitas Terbuka.

Winarni, Endang. 2012. Inovasi Dalam Pembelajaran IPA. Bengkulu: FKIP UNIB.

Wina, Senjaya. 2008. Strategi Pembelajaran; Berorientasi Standar Proses Pendidikan. Jakarta: Kencana Prenada Media Group.

Wiriaatmadja. 2009. Metode Penelitian Tindakan Kelas. Bandung: PT Remaja Rosdakarya 